ADEL AYADA

Higher Studies Israel

\title{
THE WEDDING CEREMONY AMONG THE BEDOUINS IN THE NORTH OF ISRAEL
}

\begin{abstract}
Ayada Adel, The Wedding Ceremony Among the Bedouins in the North of Israel [Ceremonia ślubna Beduinów z północy Izraela]. Studia Edukacyjne nr 41, 2016, Poznań 2016, pp. 389-402. Adam Mickiewicz University Press. ISSN 1233-6688. DOI: 10.14746/ se.2016.41.23

The paper shows a review of the changes that have occurred in the wedding ceremony and the process of the choosing of the spouse among the Bedouins in the North of Israel, in comparison between past and present, with emphasis of the changes that have occurred in this process. The findings of the research study are based on field research and observations in the Bedouin community in the North of Israel
\end{abstract}

Key words: Israel, wedding ceremony, Bedouin

\section{Introduction}

There are forms of behavior that we can understand according to accepted standards. However, there are forms of behavior or forms of life that can be understood (I do not say justified) only by the same people, and this is with the Bedouin. ${ }^{1}$

In this article I will attempt to review the changes that have occurred in the wedding ceremony and the process of the choosing of the spouse among the Bedouins in the North of Israel in the comparison between past and present, while emphasizing the changes that have occurred in this process. The

\footnotetext{
${ }^{1}$ G. Devereux, Basic Problems of Ethnopsychiatry, London 1908.
} 
findings of the research study are based on a field research and observations in the Bedouin community in the North of Israel.

In Bedouin society in the past it was customary that the woman does not voice her opinion on the issues of her marriage and officially she is not asked what she wants. Generally the negotiations on the matters of the marriage are held between the father and the groom's emissaries, and the father consults the daughter only after an agreement is achieved between the sides. Then she is asked symbolically. Generally the daughter is aware of the fact that there is no point refusing to get married after her father has given his consent. If she does refuse, then sanctions will be levied against her, when the end result is isolation.

There have been cases in the past in which a Bedouin young woman heard about the date of the wedding only a few days beforehand. There have also been cases that she did not know that she was to be married and did not know even who the groom was and on the day of the wedding she even went out to shepherd the family sheep and only in the evening was surprised when she was told to dress nicely and prepare for her wedding. In contrast, today the Bedouin young woman can choose her husband and can decide afterwards that he does not suit her.

Traditional wedding ceremonies existed in the past and celebrations lasted for more than a week, and the Bedouin still attempt to preserve the tradition of the wedding ceremony. However, with the spread of education and religion they gave way to modern or religious wedding ceremonies. The ceremony itself lasts about three days, during which the following elements are essential:

- Formulation of a 'contract' (marriage contract) by the madon (writer of the contract) who must have knowledge in reading and writing and be expert in marriage contracts. For the most part, he is a licensed man of religion.

- Presence of two witnesses (shehud). It is not important who the witnesses are. Their approval is necessary to validate the connection between the couple and in the case of divorce.

- Registration of the marriage in the Sharia court of the groom's residential region. It should be noted that a person who marries more than one woman will refrain from informing the legal authorities, so as to prevent self-incrimination according to the Polygamy Law.

In the past, weddings were held only in the summer because of the convenience of the weather. The ceremony itself is a happy event, and all the invitees eat the traditional food, rice flavored with sheep meat and a sauce 
based on goat yogurt prepared the day of the wedding. Many special candies are offered to guests.

\section{Methods}

The method entailed the participation in about 25 traditional, modern, and religious weddings (see the explanation about the types of weddings in the continuation). During these weddings I was a participative observer, documenting the songs, dances, and music, the food and the clothing. The participation contributed to my understanding.

\section{Status of the Bedouin Woman}

The life of the Bedouin also influences the Bedouin woman, as do the Muslim religion and tradition. The process of the development of the Bedouin woman began at the end of the $19^{\text {th }}$ century. In this period, a number of short stories were published in journals, primarily in Lebanon and Egypt. An example of an author from this period is the author Bilba Hashem (18801947), who published short stories at the end of the $19^{\text {th }}$ century and the beginning of the $20^{\text {th }}$ century. These were romantic and naïve stories whose content was inspired by European literature.

The revolutions that occurred in the Arab world in the 1950s (Iraq, Egypt, and Syria) accelerated the development of women. However, the main feminist activity in quantity and quality began in the 1960s, which led to changes of ancient practices.

The marriage of a young woman to a much older man was a customary practice in Bedouin folklore. Some fathers would marry their daughters to old men and they would be loyal to their parents and accept this fate. In Bedouin society the woman does not express her opinion on the matter of her marriage and officially she is not asked what she wants. Generally the negotiations on the marital matters occur between the father and the groom's emissaries, and the father seeks his daughter's counsel only after an agreement between the sides has been reached, and then she is asked symbolically. The employment of the Bedouin woman did not deviate from activity in the borders of the home and her main occupations were the preparation of food, the care for the home, and the raising of the children. 
The changes in the status of the Bedouin woman in the life of the economy and society were immeasurably slower than those of the men and entailed many more delays than the extension of education for girls. In the past, the Bedouin woman was helped by natural systems of support, such as her family of origin and her husband's family. In Bedouin society, the traditional family constituted both an economic and a social unit. All its members acted for its security and existence. The relationships of the Bedouin woman with the outside world were few and for the most part were directed by the men. In other words, it is possible to note that the Bedouin woman was surrounded by prohibitions that lead to her isolation and the limitation of her contact with strangers.

The value of honor in general and the value of the woman's honor in particular are important in the Bedouin woman's life. Harm to the Bedouin woman's honor is harm to the family and to the tribe. The woman's steps are defined and she is not permitted to pass the borders of the family in mental and physical terms. Hence, the woman's roles are determined relative to her husband. Her roles are to care for the home, to care for the family and the children. She is trained for these roles from childhood.

The system of relations between the woman and her in-laws (her father's parents) influence the quality of her life. She is addressed according to her obedience and behavior. When she is obedient and well-behaved, her life can be comfortable, and then her value to her husband is increased.

\section{Age Difference between the Husband and the Wife}

Levy ${ }^{2}$, when he addressed the age difference between the husband and the wife, notes that the marriage of a young woman to a far older man is a widespread custom in Bedouin folklore. Some fathers marry their daughters to older men and the daughters are loyal to their parents and accept their fate. In addition, he notes that in one of the queries he held in a conversation with a young woman aged eighteen who married an old man aged seventy, the woman said that she is satisfied with her elderly husband. However, two years later she left him. He says that this type of marriage emphasizes the brutality of the Bedouin towards young women. He continues with the argument that some of the young women are not interested in

2 S. Levy, The Bedouin Family in Sinai, Tel Aviv 1979, p. 126-131. 
marrying the old men because they are afraid to remain widows and defenseless.

Today the situation has changed slightly. There is a declining tendency to marry young women to old men, unless the men are rich. Alatuna ${ }^{3}$ notes that this custom exists only for the rich (primarily for building contractors), and then the young women are more easily satisfied.

\section{Exposure to Strangers}

Bedouin society took great pains on the matter of the woman's privacy. It did not permit free contact between a man and a woman and placed restrictions before foreigners so as to prevent their entry into the traditional tribal framework. To illustrate, it should be noted that in Bedouin tradition it was customary to call the curtain separating (in the residence tent) between the men and the women the mahram, namely, the forbidden.

The relationships of the Bedouin woman with the outer world were few and for the most part were undertaken by the men. In other words, it can be noted that the Bedouin woman was surrounded by prohibitions that led to her isolation and to the restriction of her contact with foreigners. Thus, for example, from the day she becomes a young woman and ready for marriage (in tribal terms) she refrains from all contact with men and her daily relations are exclusively with her mother and with members of her own sex.

The woman also maintains this principle when she is a widow or an abandoned wife. Her isolation from the outer world is anchored in traditional law, called in Arabic orfi, which dictates the rules of behavior and imposes severe sanctions for deviance and harm to the woman's honor.

Levy 4 in his research on Bedouin and the woman's freedom of mobility notes that the traditional prohibitions create a wall that isolates the Bedouin from the outside world and all her movements become more restricted. In her youth she is subject to her father and her brothers (her family) and when she is married she is subject to her husband and her children. Hondat ${ }^{5}$, in her research on the status of the Bedouin woman in the Negev, notes that the woman's freedom of mobility and status increase with her rise in age. She has a system of prohibitions and less mobility when she is young and

\footnotetext{
${ }^{3}$ M. Alatuna, The Relationship between the Status of the Bedouin Wife (Legal and Common Law) and Her Self-Image, 1993, p. 5.

4 S. Levy, The Bedouin Family in Sinai, p. 126-131.

${ }^{5}$ G. Hondat, Wives of One Husband Are a Source of Conflict, Sdeh Boker Study, 1973.
} 
when she reaches menopause and cannot have more children, her freedom of mobility increases.

Levy ${ }^{6}$ notes that in the past decade, following the transition to permanent communities and the penetration of modernization into Bedouin society, there has been a change in the woman's status. Today she is more involved in society and primarily this is typical of the young generation. In addition, there is a rise in her awareness of what is occurring around her. He attributes this change on the one hand to her exposure to the media (radio, television, etc.) and on the other hand to the influence of the daily reality, such as meetings in the health centers, the marketplace, National Insurance, and so on.

Rimlet $^{7}$ in her research study on Bedouin in the north of the country notes that although the Bedouin woman goes to work outside of the community framework, this is not a lever to the improvement of her status. In other words, Rimlet hints that tradition is still strong, still entrenched, and still dictating the woman's behavior.

\section{Giving Birth to Sons}

Rosenfeld ${ }^{8}$ notes that the preference of boys over girls derives from the fact that the boys carry the family name, constitute a source of power and respect and clan, and are intended to be responsible for the family property.

Habash $^{9}$ notes that the birth of sons reinforces the Arab woman's status, primarily in her husband's eyes, since the birth of only girls is a pretext for her husband to marry another woman. This increases the woman's level of mental tension. According to traditions and ancient customs among the Negev Bedouin, the birth of a son has always brought great joy, since the family's prestige lies in wealth and in mean. In other words, in Bedouin tradition the birth of as many sons as possible increases the Bedouin woman's status.

Stendel ${ }^{10}$ remarks that in recent years, despite the urbanization, boys are still considered preferable among the Bedouin. The birth of a daughter is not

${ }^{6}$ S. Levy, The Bedouin Family in Sinai, p. 131.

7 E. Rimlet, Patterns of Use of Services and Patterns of Employment of Bedouin Women after Their Exposure to the Process of Development: The Case of Salma Village, Records on the Topic of the Bedouin, 1991, 22, p. 53.

${ }^{8}$ H. Rosenfeld, They Were Fellahim [Peasants], HaKibbutz HaMeuchad Press, 1964, p. 54.

9 E. Habash, Processes of Change and Modernization in the Arab Family, Jerusalem 1977, p. 41.

${ }^{10}$ U. Stendel, The Status of the Arab Woman in Israel, Social Security, 1975, 9-10, p. 137. 
celebrated, while the birth of a son is, sometimes even in a Jewish event hall in the city.

This approach primarily supports the thought that the sexes have different human capital (human capital is the child's basic ability to develop working abilities, whether through studies or through innate abilities). This is in essence discrimination that derives from different attribution of capital, just or erroneous, but not discrimination for its own sake.

\section{Education}

The changes in the Bedouin woman's status in the life of the economy and society were immeasurably slower than those for the men and entailed many more delays than in the extension of the education of the girls. The expansion of the educational system created possibilities for thousands of women teachers, since it is customary for women teachers to teach girls and men teachers to teach boys. A research study conducted by the General Management of Educational Affairs in Egypt in 1950 showed that the number of women teachers in the cities of Egypt is three times the number of men teachers but that the number of Bedouin women teachers is lower. The trend in the nursing profession is lower than in the teaching profession, and most practitioners in the hospitals are men. The same holds true for the clerking profession.

Meir ${ }^{11}$ comments that nomadism constitutes an ideology from which values and norms of behavior are derived. These values and norms do not encourage the inculcation of education and sometimes cause difficulties and obstacles. The explanation is that education has Western roots and is instilled using Western methods. According to this perception, on the background of the special lifestyle, the tendency among the traditional Bedouin, namely those who live in tribes far from permanent settlements, is not to send their children to acquire a formal education since they have not internalize education as an important value.

Levy ${ }^{12}$, who studied the Negev Bedouin, found that the education of the Bedouin woman also does not exceed the bounds of the tribe and her main learning is from her mother. She learns tasks such as cooking, weaving, and house upkeep, including cleaning, etc.

11 A. Meir, Delivering Essential Services to Arid Zone Nomads, [in:] Desert Development: Men Technology in Sparse Lands, Ed. Y. Gradus, Dordrecht 1985.

12 S. Levy, The Bedouin Family in Sinai, p. 130. 
Ariel ${ }^{13}$ notes that despite the strong tendency of Israeli Arabs to adopt a modern style, the hand of Islamic tradition nevertheless trumps their professional progress. Hence, among Bedouin women a conflict is created between the rigid patriarchal regime and the more open possibilities for change in the public circle. As support of these opinions, we see the development and shift in the direction of the increase of the number of girls studying in formal educational frameworks and some even obtain a higher education. However, conversely there still is assignment of limitations and prohibitions, and when there is a clash between the two elements (education versus traditional values), it seems that tradition has the upper hand.

\section{Marriage}

In Bedouin society, the woman does not express her opinion on the issue of her marriage and officially she is not asked what she wants. Generally the negotiations on the issue of her marriage are held between the father and the groom's emissaries and the father seeks his daughter's counsel only after an agreement has been reached between the sides and then she is asked symbolically. Generally the young woman is aware of the fact that there is no point in refusing after her father has consented, since if she refuses sanctions will be imposed against her and the end result is isolation. ${ }^{14}$

Hence, the woman tends to accept her fate without knowing anything about her intended groom's appearance, nature, and character. In addition, the professional literature notes that the choice of the spouse and the timing of the marriage are at the father's exclusive discretion. This phenomenon has been addressed often in the professional literature and has been described as contributing to the family cohesion, although generally the marriage is forced on one of the couple.

In our time, the situation has changed slightly. However, the first stage of negotiations between the father and the groom's emissaries still exists. Then the daughter is asked her opinion, but her refusal does not necessarily mandate social isolation. The government institutions, primarily in Israel, provide help for this young woman, if she appeals for help. However, on the one hand, naturally very few young women ask for help and on the other hand, the government agencies find it very difficult to intervene in the

${ }^{13}$ M. Ariel, The Education of Women, Intelligent Investment or Gambling on the Wrong Horse, Venus, 1988, 16, p. 30.

${ }^{14}$ M. Alatuna, The Relationship between the Status, p. 10. 
tribe's internal matters. Moreover, this type of affair detrimentally impacts honor for the tribe.

In any event, the abduction of the bride, which was customary in the past when the negotiations between the father and the groom's representatives failed, barely exists today. Furthermore, bridal abduction is a criminal offense according to the country's laws. The most popular marriage is the mohar marriages. In Bedouin culture, mohar is a certain compensation paid for the young woman's departure from her parents' home, to compensate for the fact that she has become the wife of the mohar payer and depends exclusively on him. Generally the mohar is determined according to the degree of family closeness between the couple. If they are cousins, then the mohar has on ritual significance and its sum is symbolic. ${ }^{15}$

This phenomenon exists today, despite the modernization, among the Bedouin in the north of the country, as well as among the Bedouin in the south of the country. The explanation for the existence of this phenomenon is not basically different: when the family has a young woman, the attempt is made to solve this problem by having the young woman's brother marry another young woman. In other words, this is a method of exchange, when the concern is for the daughter not to remain single.

Habash $^{16}$ notes that the exposure of traditional society to mass media and the creation of intensive relationships with urban society are two decisive factors in the creation of processes of change in the area of marriage.

\section{Types of Weddings}

The first type of wedding is the traditional wedding. This wedding is held in the groom's parents' home. Generally many people are invited, and there is a nearly total separation between men and women. The common dance in this type of wedding is debka (a traditional Bedouin dance for men only). The food served to the invitees is generally rice and lamb. The gifts do not need to be cash money but can be presents for the couple or for their new home.

The second type of wedding is a modern wedding. This type of wedding has begun to become popular among the Bedouin in the north of Israel. Generally this event is held in an event hall or garden near the village. The

\footnotetext{
15 A. Sabak, Chapter of Alsuna, Beirut 1987, p. 10.

${ }^{16}$ E. Habash, Processes of Change and Modernization, p. 40.
} 
dances can be diverse, and the music is Western in style. There is no separation between men and women. The food is varied. The gifts are cash money.

The third type of wedding is a religious wedding, which in essence is a wedding held in the groom's parents' home. Its characteristics are similar to those of the traditional wedding. However, there is barely any music. Verses from the Quran are read or praise of the Prophet Mohammed is stated. It must be stated that in this wedding there is no dancing.

\section{Polygamy}

Polygamy is the most common form of marriage in the Muslim world. However, since this practice is based on a Quranic Surah (chapter), there are different interpretations.

Surah 4:3 states that a man can marry four women at once only if he can treat all four of them equally. However, later in this Surah it is stated that men can never, despite all their efforts, provide equal reference to their wives. This Surah and others constitute the source of the arguments between liberal modernists and conservatives. In this case, the dispute is whether the Quran intended to encourage, permit, deter, or prohibit polygamy.

The polygamous approach dominated for years among the Bedouin tribes. However, in the past century anti-polygamous approaches have developed. These approaches did not arise following textual changes and different interpretations of the Quran but because of the social changes the Bedouin experienced in this century. ${ }^{17}$

Nevertheless, despite these approaches, polygamy still exists, although to a reduced extent. It primarily is found among the rich, who can afford to pay for it.

\section{Obedience to the Husband}

As aforementioned, the Bedouin, although they are not Muslims in the full sense of the word, have adopted for themselves the roots of the woman's status in Islam, which lie in hundreds of years of tradition. The Quranic approach, as expressed in the $17^{\text {th }}$ century by Mohammed Bakir

${ }_{17}$ M. Michael, G. Fischer, Iran from Religious Dispute to Revolution, London 1980, p. 162. 
Majelsi, holds that "the woman must heed all her husband's orders and when they are alone she must submit willingly to all his demands". 18

It is difficult to find in the Islamic sources a cohesive approach regarding the woman's status. The differences between the different periods and different divisions in Islam can be attributed to different interpretations. Some maintain that the inferiority of women in Islam was exacerbated by the erroneous interpretation of Islamic dictates that were confirmed by the religious institutions ${ }^{19}$.

What makes Islam unique is the fact that most of the questions that address the woman's rights and status were legislated by the Quran and the Hadith (reports of the words and actions of the Prophet Mohammed). Thus, there is the basic problem of interpretation and renewal. In the Quran itself there are Surahs that speak about equality for women while other Surahs speak about the subjugation of women to men.

A basic approach accepted according to Surah 4:1 is that the woman and the man are equal since they were created at the same time, from the same material, and by the same Creator. Although most of the educated people and philosophers accepted this approach, some attempted to present the man as superior. It should be noted that many accuse the religious leaders of the distortion of the Quranic Surah on this matter. ${ }^{20}$

Another Surah, Surah 4:34, states that "men are in charge of women since Allah made them more excellent and since they spend their property (to support women)". ${ }^{21}$. This Surah legitimizes another basic perception that the man is superior. This perception was given many reinforcements over the years and eventually led to the perception of the religious commandments, the religious leadership, the witnessing, the jihad, the worship in the mosque, and so on as the exclusive province of the man.

Between the difficulty in understanding the true meaning of the Quranic revelation as an expression of God's will and the efforts undertaken to go beyond the meaning of the words, the woman's precise status and role in Bedouin society has suffered, always, from lack of clarity that can barely be resolved. Regarding women, it is possible to find different sermons that ex-

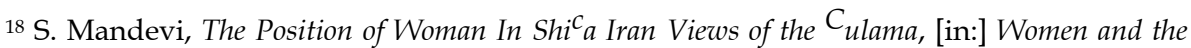
Family in the Middle-East, Ed. E. Warnock Fernea, 1985, p. 265.

19 A. Haleh, The Legal, Social and Political Position of Women in Iran, International Journal of the Sociology of Law, February 1985, 13, p. 14.

20 A.K. Ferdows, The Status and Rights of Women in Ithna Ashri Shi ${ }^{\mathcal{C}}$ Islam, [in:] Women and the Family in Iran, Ed. A. Fathi, E.J. Brill, Leiden 1985, p. 14.

${ }^{21}$ Ibidem, p. 16. 
press completely different approaches. One sermon notes that women are deficient in terms of faith, intellect, and inheritance. They are deficient in their religious belief since they are absent from the prayers and the religious holidays during their monthly menstruation. They are deficient in their intellect because the testimony of two women is equivalent to that of one man. They are deficient in terms of their inheritance since a woman inherits half of what a man inherits. Therefore, women should not be obeyed even if they have good intentions, so that they will not draw the man to evil..22

The life of the Bedouin woman is not disconnected from the lifestyle of the family and tribe, in all the stages of the transition from childhood to youth to marriage. The obedience and subservience to the man are absolute, when the man is in the position of her father or the position of her husband. Children are born into this idea and raised according to it. The social and family status of the married Bedouin woman is determined, set, and nurtured by this idea, which shapes her path throughout her entire life. As long as she upholds these rules, her honor, her body, and her livelihood are ensured and protected. ${ }^{23}$

The Bedouin woman from her birth is the man's property and asset. She has no existence in her own right. Hence, the birth of a daughter is not celebrated at all among the Bedouin. According to this perception, her marginal image inspires dissatisfaction, since in her family's eyes she sometimes constitutes a bother, even after her marriage, and sometimes she even erodes the peace at home. ${ }^{24}$

\section{Divorce}

Today divorce is more common in Bedouin society. However, the percentage of divorce is in the single digits, unlike in non-Bedouin society. A divorced woman is of less value in Bedouin society

Divorce was extensively used in pre-Islamic society by both men and women. One of the main questions on the topic of divorce in Islam is the power of unilateral divorce granted to the man and the negation of this right from the woman. In other words, the practice is what gives the man the exclusive right to divorce at any time he wants, without a legal process and without the woman's knowledge.

\footnotetext{
22 Ibidem.

23 A. Cohen, The Arab World of Our Time, Merhavya 1958, p. 204-209.

${ }^{24}$ S. Levy, The Bedouin Family in Sinai, p. 131.
} 
Islam did not change the practice but rather set certain conditions that only delineate whether the divorce is valid. Aside from the condition that the announcement of the divorce must be in the Arabic language and adhere to precise specific language, there are conditions about the woman's purity, a certain period of waiting, and the required sums of money..$^{25}$

When society goes to decide on the matter of child custody in the case of the conflict and separation between the spouses, Bedouin society preferred and still prefers, almost without exception, the father as the custodial parent over the mother. From a traditional perspective, the decision derived from the principle of the 'good of the child', namely, the good of the child is seen as for the child to grow up in his father's tribe and to be educated in the tribe's values. The situation is even strengthened when discussing the custody of the girl (family honor). As aforementioned, modern society finds it difficult to see this to be the 'child's good because of the equal perspectives and the rationale behind every approach.

\section{Conclusion}

This paper addressed the Bedouin woman's status in the past and in the present, through the explanation on the wedding and the marriage process. This process includes the discrimination against the Bedouin woman in the comparison to the man, the distancing of the Bedouin woman from the company of men, and the prevention of the open and declared cooperation in the making of the decisions. The paper illustrates the difficulty of the observer from modern society with the understanding of enrooted social patterns, about the woman's status.

It was found that the woman's status has changed greatly with the transition to modernization. However, a steadily increasing number of women learn in outside institutions, and some of them work in government institutions. However, the man is still the one in control, the woman is still the one controlled, the one who obeys her husband's will. Topics such as marriage and divorce have also changed over the years.

It must be noted that in traditional and modern weddings there are exceptional phenomena that inspire conflicts, such as the entry of the young people into the dance arena. These phenomena draw from cultural tradition of the past that shed light to a certain degree until today about the Bedouin

${ }^{25}$ A.K. Ferdows, The Status and Rights of Women, p. 26-28. 
wedding, in comparison to the permissiveness in the modern Bedouin wedding, with all its modern characteristics that conflict and constitute a threat to the Bedouin tradition.

\section{BIBLIOGRAPHY}

Alatuna M., The Relationship between the Status of the Bedouin Wife (Legal and Common Law) and Her Self-Image and Psychological Wellbeing, Bar Ilan University, 1993. (Hebrew)

Ariel M., The Education of Women, Intelligent Investment or Gambling on the Wrong Horse, Venus, 1988, 16. (Hebrew)

Cohen A., The Arab World of Our Time, Merhavya, 1958. (Hebrew)

Devereux G., Basic Problems of Ethnopsychiatry, London 1908.

Ferdows A.K., The Status and Rights of Women in Ithna Ashri Shi ${ }^{\mathrm{C}}$ Islam, [in:] Women and the Family in Iran, Ed. A. Fathi, E.J. Brill, Leiden 1985.

Habash E., Processes of Change and Modernization in the Arab Family, The Institute for the Research of Labour and Welfare, Jerusalem 1977. (Hebrew)

Haleh A., The Legal, Social and Political Position of Women in Iran, International Journal of the Sociology of Law, February 1985, 13.

Hondat G., Wives of One Husband Are a Source of Conflict, Sdeh Boker Study, 1973. (Hebrew)

Levy S., The Bedouin Family in the Sinai, The Society for the Protection of Nature, Tel Aviv 1979. (Hebrew)

Mandevi S., The Position of Woman In Shica Iran Views of the Culama, [in:] Women and the Family in the Middle-East, Ed. E. Warnock Fernea, Texas University Press, 1985.

Meir A., Delivering Essential Services to Arid Zone Nomads, [in:] Desert Development: Men Technology in Sparse Lands, Ed. Y. Gradus, Dordrecht 1985.

Michael M., Fischer G., Iran from Religious Dispute to Revolution, Harvard University Press, London 1980.

Rimlet E., Patterns of Use of Services and Patterns of Employment of Bedouin Women after Their Exposure to the Process of Development: The Case of Salma Village, Records on the Topic of the Bedouin, 1991, 22. (Hebrew)

Rosenfeld H., They Were Fellahim [Peasants], HaKibbutz HaMeuchad Press, 1964. (Hebrew)

Sabak A., Chapter of Alsuna, Beirut 1987. (Arabic)

Stendel U., The Status of the Arab Woman in Israel, Social Security, 1975, 9-10. (Hebrew) 